\title{
agriculture
}

ISSN 2077-0472

www.mdpi.com/journal/agriculture

Review

\section{Managing Soil Erosion in Northern Ireland: A Review of Past and Present Approaches}

\section{Donal Mullan}

School of Natural Sciences and Psychology, Liverpool John Moores University, Liverpool L3 3AF, England, UK; E-Mail: D.J.Mullan@ljmu.ac.uk; Tel.: +44-151-231-2175

Received: 25 June 2013; in revised form: 18 September 2013 / Accepted: 30 September 2013 /

Published: 15 October 2013

\begin{abstract}
In recent decades, the off-site transport of sediment and nutrients from agricultural land into the neighbouring natural and built environment has become a more pressing environmental sustainability issue than the on-site threats of soil erosion in many of the world's temperate regions. In the temperate region of Northern Ireland, recent studies have highlighted the off-site issue of soil erosion by water in the present day, and projected that the problem may become more widespread and serious in a changing climate. This review paper examines how this problem is being managed in the present day, and draws on examples of policy in other countries to consider how the role of policy needs to be modified for more effective management. Farmers are generally not adhering to present-day policy and "keeping their land in good agricultural and environmental condition". A range of suggested changes in policy and practice is offered, ranging from educating farmers on erosion mitigation and remediation to developing specific policies aimed at targeting soil erosion and conservation as their sole objective. An increase in the evidence base from measured erosion rates in the field is postulated to be the most likely route to achieving policy changes.
\end{abstract}

Keywords: soil erosion; muddy floods; off-site impacts; policy; farmers; agriculture

\section{Introduction}

Although a natural process which has been operating on landscapes throughout the world since the dawn of settled agriculture [1,2], soil erosion has been greatly accelerated by human activity owing to the clearance of natural ecosystems into agricultural land and the associated working of that land [3]. This has led to a reduction in soil quality and overall agricultural productivity [1]. Termed the 
"on-site" impacts of soil erosion, issues include reduced water and nutrient-holding capacity of the soil [4,5]; reduced organic matter content [6]; and reduced soil depth to support roots and organisms [7,8]. The "off-site" impacts, meanwhile, consider the fate of soil when particles leave the agricultural land. Adverse off-site impacts include the economic consequences when large quantities of suspended sediment are transported from fields and into homes, settlements and infrastructure in "muddy floods" [9], and the environmental damage associated with sedimentation of sand and gravel-bedded rivers [10] and the adsorption of chemicals onto soil particles and eutrophication of water bodies [2]. A more detailed account of the on-site and off-site impacts of soil erosion can be found in [11].

In the temperate region of Northern Ireland, recent studies [11-15] have highlighted the present-day off-site problem of soil erosion, and have projected that soil erosion could become a more serious issue under the impacts of a changing climate. The most direct of these impacts are changes in the erosive power of rainfall [16-20]. With an increase in the moisture-holding capacity of the atmosphere at a rate of $c a$. $7 \%$ per $1{ }^{\circ} \mathrm{C}$ rise in temperature (sensu the Clausius-Clapeyron relationship), a more vigorous hydrological cycle is created, modifying precipitation characteristics such as amount, frequency, duration, intensity, and their extremes [21]. Indirectly, increases in temperature and $\mathrm{CO}_{2}$ concentrations can drive changes in plant biomass, with increasing erosion rates possible due to faster residue decomposition and increased microbial activity [22], and decreasing erosion rates possible owing to an increased soil surface canopy and biological ground cover [23]. In addition, farmers may wish to take advantage of new climatic conditions by adapting the timing of their agricultural operations, with changing planting and harvesting dates and the implementation of new crops all factors with the potential to considerably alter the rates and patterns of soil erosion [22].

Given the present-day problem and future potential for a greater soil erosion problem in Northern Ireland, it is vital that policy is in place to reduce the harmful off-site effects. A review of soil erosion policies has been documented for many countries, including Belgium [24]; Czech Republic [25]; Germany [26]; Norway [27]; Spain [28]; and United Kingdom (England and Wales only) [29,30]. National erosion policies are generally lacking, but EU subsidies and voluntary agri-environmental schemes indirectly have consequences for soil erosion control. The Soil Thematic Strategy [31] is a European Soil Policy which works to ensure sustainable use of the soils of Europe through preventing further soil degradation and preserving its functions, as well as restoring degraded soils to a level of functionality consistent with its intended use [31]. Among the four pillars of the Thematic Strategy is integration with the Common Agricultural Policy (CAP), which has an important role to play in soil management [32]. The EU CAP [33] indirectly requires farmers to exercise erosion control as they must keep their land in "Good Agricultural and Environmental Condition" (GAEC) to qualify for subsidy payments. GAEC guidelines [34] include stipulations on land management between harvesting and planting, such as planting of cover crops or leaving stubble of the harvested crop on the land [34]. The Water Framework Directive (WFD) is an EU directive which, like the CAP, possesses an indirect requirement on farmers to control erosion and its off-site impacts to maintain "good ecological status of surface waters" [35]. In individual EU countries, agri-environmental schemes are also in operation, which can provide additional indirect incentives to farmers to control erosion from their land. Soil erosion in Northern Ireland is indirectly managed by many of these EU and national directives and agri-environmental schemes, with guidelines on farmer practices from commissioned reports also 
acting as an avenue for encouraging (but not enforcing or even incentivizing) management. The report "Climate Change, land management and erosion in the organic and organo-mineral soils in Scotland and Northern Ireland" [36] included information on present and future drivers of soil erosion, and offered advice on methods for erosion reduction, such as confining sheep grazing in erosion-prone areas to the growing season. This report is the only government-funded commissioned piece of work which relates to soil erosion and erosion management issues in Northern Ireland.

The aim of this paper is to review policies directly or indirectly aimed at reducing soil erosion and its off-site impacts in Northern Ireland, and evaluate the effectiveness of these policies for the past and present day. Drawing on evidence of successful approaches to soil erosion policy in other countries, the paper will then consider how policies could be revised for effective management of the soil erosion problem in the future.

\section{Approaches and Barriers to Managing Soil Erosion in Northern Ireland}

\subsection{Past and Present-Day Policies}

Since agricultural and more recently "agri-environmental" policies dictate subsidy payments to farmers for agricultural production and environmental awareness, they are fundamental to managing the on-site and off-site impacts of soil erosion. In Europe, two contrasting policy phases are considered, with each bringing about a different response of soil erosion and its associated impacts. These can be divided into (1) agricultural policies encouraging intensive food production post-World War 2; and (2) agri-environmental policies with a more environmental focus following the United Nations Conference on Environment and Development (UNCED) or "Earth Summit" in Rio de Janeiro in 1992.

\subsubsection{Agricultural Policies Post-World War 2}

The most significant agricultural policies affecting the on-site and off-site impacts of soil erosion in the UK (including Northern Ireland) arose from the implementation of the European Union (EU) CAP in 1962 and its incorporation into UK agricultural policy following its inception into the EU in 1973. The CAP was established in order to boost European food production in the face of post-war shortages and increasing farm incomes, supported by subsidy payments to farmers for agricultural production [37]. Accompanying this drive towards agricultural intensification were a number of changes which began through the earlier Agriculture Act (1947) in the UK. Such changes included the application of more fertilisers [38]; higher yielding cereal varieties [39]; the introduction of pesticide use; use of bigger and heavier machinery; the removal of hedgerows and field boundaries [40]; a decrease in the number of holdings and workers; an increase in farm size [41]; and a large increase in winter cereals by a factor of about three, particularly in England and Wales [42]. All such practices were designed to facilitate more efficient agriculture and higher agricultural productivity per hectare, but had the added effect of markedly increasing the vulnerability of the land to runoff and erosion across England and Wales [43]. Although only limited measured data exist to assess the problem in the study area, past evidence for soil erosion in Ireland [12,14,44] indicates that the drive towards 
agricultural productivity had the effect of resulting in widespread erosion across many parts of the island.

\subsubsection{Towards Agri-Environmental Policies}

With the growing recognition that agricultural intensification was affecting not only soils but also the wider environment (e.g., [7]), reforms to the CAP since the late 1980s adopted a more environmental focus, including the introduction of voluntary set-aside in 1988 and compulsory set-aside in 1992 to reduce the production of combinable crops [29]. Although not implemented as a direct measure to reduce soil erosion, a number of case studies in England [44-48] documented the success of set-aside on slopes vulnerable to erosion in reducing soil loss and leading to a decline in connectivity of flow from field to field and field to watercourse, thereby also reducing problems associated with the off-site impacts of erosion.

A review of the CAP in 1999 [49] led to greater emphasis on environmental protection and conservation of the countryside in addition to food production. To receive payments via the Single Farm Payment (SFP) scheme (2005), farmers would have to keep their land in good condition and for the first time would have to ensure erosion and runoff from their land was minimised [29]. As part of the SFP, farmers were also encouraged to enter agri-environmental schemes such as the Countryside Management Scheme (CMS) or Environmentally Sensitive Areas (ESAs) in Northern Ireland. Through such schemes, farmers are offered financial incentives to maintain and enhance biodiversity and assist the implementation of the WFD [35]. The latter was incorporated into UK law in 2003 as a piece of legislation to protect and enhance water quality. Under the directive, the chemical and ecological conditions of all inland and coastal waters should not deteriorate from their present state and must be of "good surface water status" by 2015 [35]. Similar to the qualification criteria for receiving subsidy payments through the SFP, the WFD ensures farmers must take account of erosion and runoff from their land, and are responsible for ensuring that off-site impacts of erosion from their land does not compromise "good water surface status" by 2015. The Farm Nutrient Management Scheme (FNMS) was introduced in 2005 to provide farmers with financial incentives to increase their slurry storage capacity, thereby ensuring more efficient use of available nutrients and reducing the runoff of nutrients into surface waters [50]. In this respect, the FNMS also seeks to achieve compliance with the WFD in ensuring good water quality standards in Northern Ireland. A summary of the main agri-environmental policies indirectly affecting soil erosion in Northern Ireland is shown in Table 1.

Table 1. Main agri-environmental policies indirectly affecting soil erosion in Northern Ireland and their objectives.

\begin{tabular}{|c|c|c|}
\hline Year & Policy & Objective \\
\hline 2003 & Water Framework Directive & $\begin{array}{l}\text { To achieve good ecological and chemical status } \\
\text { in surface waters }\end{array}$ \\
\hline 2005 & Single Farm Payment & $\begin{array}{l}\text { To keep land in good agricultural and } \\
\text { environmental condition }\end{array}$ \\
\hline $2007-2013$ & $\begin{array}{l}\text { Countryside Management Scheme/ } \\
\text { Environmentally Sensitive Areas }\end{array}$ & $\begin{array}{l}\text { To improve the environment and the } \\
\text { countryside through land management }\end{array}$ \\
\hline 2005 & Farm Nutrient Management Scheme & To reduce nutrient runoff to surface waters \\
\hline
\end{tabular}




\subsection{Are Present-Day Policies Helping to Reduce Erosion?}

\subsubsection{Policy Effectiveness in Reducing Erosion}

As noted in the previous section, a number of studies from England [44-48] have highlighted the success of set-aside of land on slopes vulnerable to erosion. In the early 1990s in the South Downs, England, one particular farmer put some of his land into set-aside since it had been flooding a downslope housing estate since the mid-1980s with sediment from his eroding land. The farmer was able to take this action without loss of subsidy due to the introduction of voluntary set-aside in 1988 and compulsory set-aside in 1992 as part of the CAP. Since set-aside, the housing estate has never been flooded, not even during the winter of 2000/01 when many other estates suffered muddy floods [29]. There are also instances, however, where agri-environmental policies can lead to increased erosion. It has been demonstrated through field observations and modelling studies in Spain that set-aside can lead to increased soil erosion due to the treatment of set-aside land as unseeded fallow [28]. Land is left as unseeded fallow to increase soil moisture and fertility for subsequent rotations due to the semi-arid nature of the Mediterranean climate. With low annual rainfall totals in many parts of Spain, intensive cropping exhausts soil resources of water and nutrients, meaning unseeded fallow is one means of restoring fertility for future crop rotations [28]. Although set-aside in the temperate climate of Ireland is unlikely to result in a similar land management in the present day, climate change projections illustrate future summer drying [51,52], indicating that increased erosion due to the treatment of set-aside land as unseeded fallow could be a possibility in the future. Of course, by this time, set-aside may no longer act as a funded agri-environmental policy due to the changing nature of the policy landscape.

\subsubsection{Issues of Farmer Compliance}

Although the range of policies designed to improve water quality and concern for the wider environment look as though they may provide the answers to reducing the effects of soil erosion, the situation in reality may be more complicated. This is because, according to [29], many farmers in Britain are not complying with recent agri-environmental policies and keeping their land in "good agricultural and environmental condition". Personal observations in Northern Ireland support this, where numerous incidences of erosion have been spotted over a three year period between 2008 and 2011 (Figure 1) [14].

There may be various reasons responsible for lack of compliance. Firstly, since UK policy is designed primarily to reduce the off-site impacts of erosion such as diffuse pollution and muddy floods rather than the on-site conservation of soil, the cost of failure to comply with policy regulations is no greater to the farmer than it is to the general tax-paying public. In Northern Ireland, lack of compliance with mandatory regulations and uptake of voluntary regulations may be a greater problem than it is in Britain. This is because colloquial evidence suggests that farmers in Northern Ireland generally do not consider soil erosion to be a problem. When the father of the author, a local farmer, was asked whether he would consider applying for the CMS, he replied no because he thought the scheme was "eejiting" (Irish slang for foolishness). Whether his views are representative of the farming community in Northern Ireland requires further research, but the general lack of concern amongst farmers regarding 
the impacts of soil erosion is evident. The second possible reason for lack of compliance with policy regulations is because of the relatively subjective nature of the policy objectives with respect to environmental issues. Statements such as "to achieve good water surface status" and "to keep land in good agricultural and environmental condition" (see Table 1) are open to interpretation and thus easier for farmers to evade and still receive subsidy payments.

Figure 1. Five separate soil erosion events on agricultural land in County Tyrone between 2008 and 2012. (A) Loughmuck, Omagh, Co. Tyrone; (B) Ballynahatty, Omagh, Co. Tyrone; (C) Kevlin, Omagh, Co. Tyrone; (D) Aughafad, Clogher Valley, Co. Tyrone; (E) Blackfort, Omagh, Co. Tyrone.
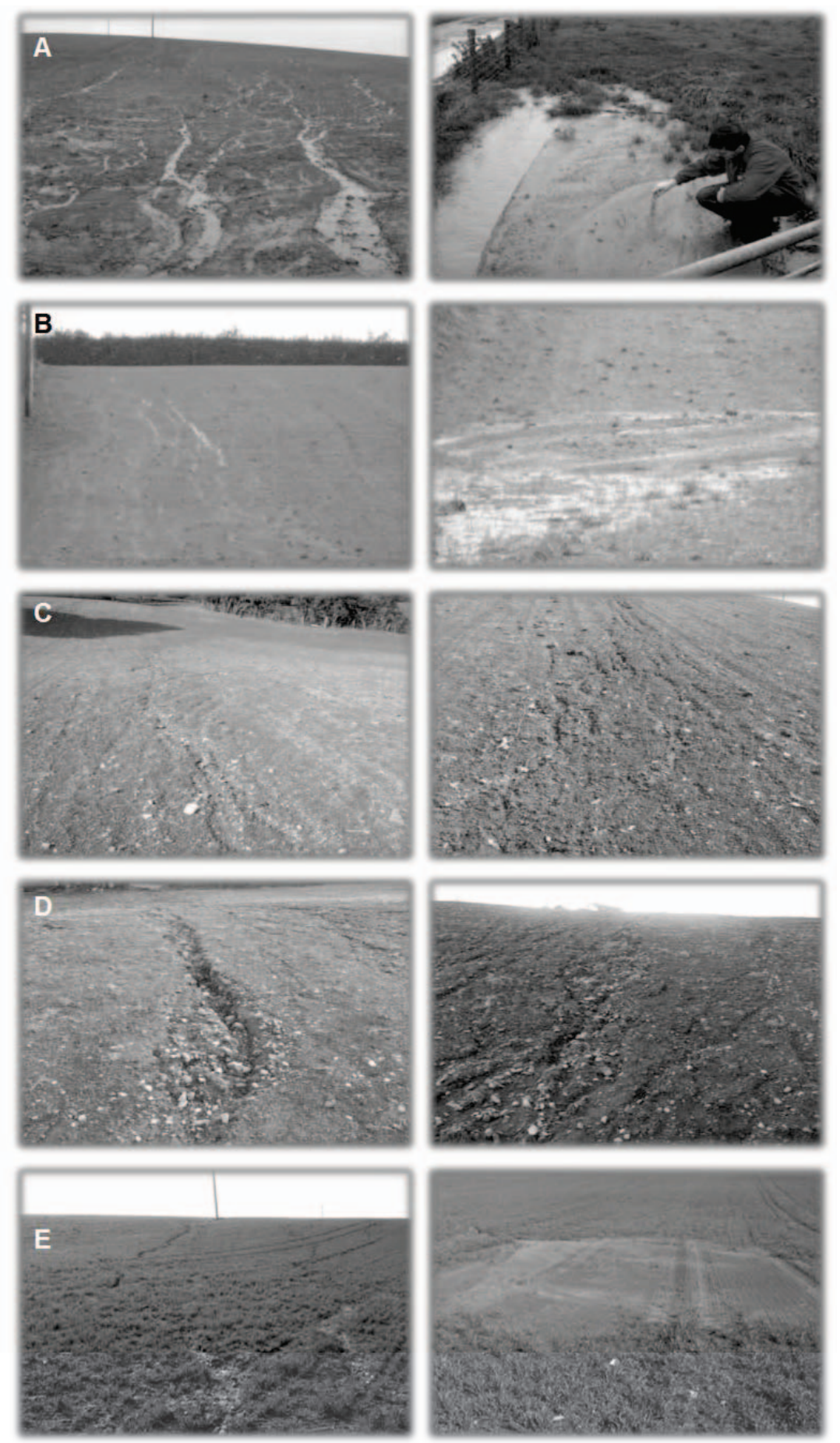


\section{Future Policy Considerations for Northern Ireland}

Given the potential for increased soil erosion under the impacts of future climate change in Northern Ireland (see Figure 2) [11,15], the need for greater enforcement with respect to existing agri-environmental policies and/or the development of a new set of policies developed specifically to tackle soil erosion from agricultural land may be required. In order to be robust and long-term, future policy changes should be (1) based on experience; (2) relevant to a wide range of possible future climatic conditions; and (3) cognisant of the many possible agents of societal change [53].

Figure 2. Percentage change in soil loss for three future time periods relative to the modelled present-day baseline erosion rate for six hillslopes in Northern Ireland under future climate and land use change scenarios [15]. The full distribution at each hillslope accounts for 216 future scenarios ( 3 GCMs $\times 2$ emissions scenarios $\times 3$ ensembles $\times 4$ land use scenarios $\times 3$ future time periods). Lower whisker: minimum; lower box line: 25th percentile; middle box line: median; upper box line: 75th percentile; upper whisker: maximum. LMK: Loughmuck; DUN: Dunadry; COR: Corrard; LGL: Loughgall; HIL: Hillsborough; BAL: Ballywalter.
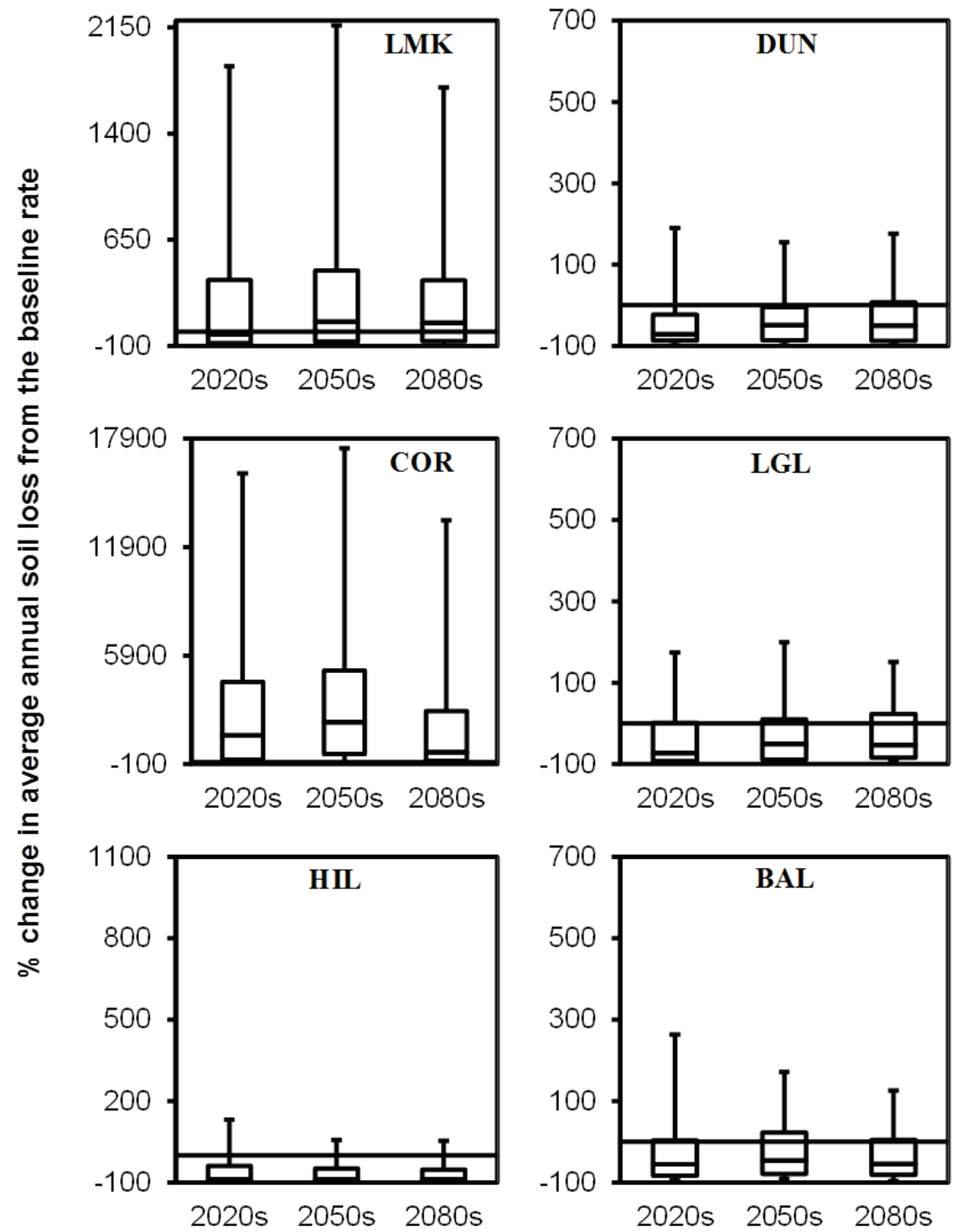


\subsection{Clearer Definitions for Environmental Standards}

As stated previously, qualitative statements with respect to achieving environmental standards clearly makes it easier for farmers not to fulfil them and still receive subsidy payments. An exception is the EU Fish Directive [54], where guideline values are in place for EU member states to keep suspended solids and nutrient levels in surface waters below certain thresholds, e.g., $\leq 25 \mathrm{mg} / \mathrm{L}$ of suspended solids and $\leq 0.01 \mathrm{mg} / \mathrm{L}$ of nitrites in salmonid waters [55]. If a more rigorous metric was in place, then farmers would be under greater pressure to minimise erosion from their land in order to meet the requirements of their subsidies. In terms of enforcement, the EU may wish to consider implementing a water quality target through its WFD scheme in the same way as the $1 \mathrm{t} / \mathrm{ha} / \mathrm{year}$ limit set by USDA for the USA [56] to control pollution from sediment and maintain water quality standards. A threshold for on-site problems could also be set, e.g., those set in [56].

\subsection{Greater Enforcement of Subsidy Requirements}

In addition, the regularity of inspections and penalties for breaching rules as part of any subsidy or agri-environmental scheme may need to be revised to ensure greater land management and environmental responsibility. Under the SFP, for example, the penalty for failure to comply with keeping land in good agricultural and environmental condition is just 3\% of the annual subsidy payment [57], which is unlikely to be a considerable enough deterrent to farmers to ensure soil erosion from their land is at the forefront of their consciousness. Consideration may be given to heavier penalties for breaching cross-compliance.

\subsection{Raising Awareness through Education}

The reduction of soil erosion and the runoff of sediment and associated chemicals and fertilisers into nearby water courses is a central objective for "keeping land in good agricultural and environmental condition" as part of the cross-compliance regulations for SFP payments and as part of the conditions for meeting a number of agri-environmental schemes. Despite this, none of these policies make any reference to how individual farmers should address the issue. Up until the inception of the SFP in 2005, awareness of soil erosion and methods to alleviate it were only available to local farmers in the UK through pamphlets distributed by organisations such as the Ministry of Agriculture, and Forestry and Fisheries (MAFF) (now the Department of Environment Food and Rural Affairs: DEFRA) [58,59]. As part of the cross-compliance for SFP subsidy payments from 2005 onwards, the "Guidance for Soil Management" [60] states that farmers in England must "consider the risk of runoff and erosion when planning what to grow" and advises that "where severe erosion occurs, earth banks or other physical barriers may be used as a last resort to check the flow of water and reduce off-site impacts". This is the only piece of soil conservation advice currently written into UK policy. It is important to note, however, that this applies only to England and is not part of the SFP cross-compliance policy in Northern Ireland. In this respect, whilst policies exist that require farmers to minimise erosion from agricultural land (amongst other objectives) in Northern Ireland, no advice is offered in terms of prevention through effective land management or remedies to the problem when erosion actually occurs. 
Education is a critical step in helping to minimise erosion and its off-site impacts. Information needs to be made available to local farmers regarding the recognition of soil erosion in their fields, as well as advice on how to prevent erosion through effective land management and deal with the problem if erosion does occur. An approach similar to the pamphlets developed by MAFF in England in the mid-1980s may be a good starting point to help raise awareness of soil erosion and its adverse impacts amongst farmers in Northern Ireland. Taking this action in the present-day may help alleviate present-day off-site impacts of soil erosion through better land management, whilst also providing an early platform to build recognition amongst farmers with respect to the potential for increased soil erosion.

\subsection{Implementation of Conservation Strategies}

In other EU countries, examples exist whereby conservation strategies are written into agricultural or agri-environmental policy. Taking Flanders, Belgium as a particular case study, as part of the cross-compliance for the Single Payment Scheme (SPS) (equivalent to the SFP in Northern Ireland), farmers whose fields are classified as very susceptible to erosion must control the problem through at least one "farmer's action". Typical farmer's actions include the implementation of cover crops, contour tillage, grass buffer strips and conservation tillage [24]. Given the potential for muddy flooding and other severe off-site effects of erosion under certain future scenarios in Northern Ireland, there may be a case that future policies could include the stipulation that a soil conservation technique is implemented in areas susceptible to erosion, as is the case in present-day Belgium. This would require the development of a soil erosion risk assessment procedure similar to that developed by DEFRA [59] and assessed by [10] for controlling water erosion in England, in order to enable vulnerable areas to be targeted for conservation practices. Indeed the existing DEFRA scheme for England could be directly implemented in Northern Ireland. Any such conservation should fulfil the low-regret, reversible, flexible, low-cost and "soft solutions" approach that targets protecting the soil surface from raindrop impact and runoff by means of permanent vegetation rather than hard engineering [24].

There have also been a number of instances where conservation strategies have been advised in individual legal cases in England, where muddy floods caused disruption to nearby properties. When houses and roads suffered muddy flooding in the winter of 2000/2001 in Suffolk, England originating from a field of outdoor pigs, a map was produced (Evans, unpublished) showing where grass margins could be implemented to protect the most vulnerable slopes and thus reduce runoff and erosion in future years. When this proposal was implemented following threat of legal action, no flooding to properties or major roads occurred [29]. In 2001 a similar case study from an outdoor pig field in Suffolk resulted in a court case settled in favour of the plaintiff following muddy flooding of a property, with the consequence that parts of two fields can no longer be used for rearing pigs [61]. Given the potential for increased muddy flooding in Northern Ireland over the coming century (See Figure 2) [11,15], these sorts of legal cases may become prevalent in the future. Again, this provides further weight to the argument that risk maps would be useful to identify the most susceptible areas to muddy floods to help target mitigation measures. The DEFRA risk mapping criteria for 
England and Wales could be used. It is acknowledged, of course, that the challenge would then become getting farmers to adopt control measures resulting from this mapping.

\subsection{Specific Agri-Environmental Measures}

Again, looking towards Flanders, Belgium as a notable case study, there exist agri-environmental schemes designed to tackle soil erosion as their primary objective as part of the Flemish Rural Development Programme, driven by local authorities and residents of flooded villages [38]. The crucial element with this example is the financing model used in Flanders. Since the Erosion Decree in 2001, municipalities in the Flemish region became eligible for subsidies to draw up an erosion mitigation scheme on a voluntary basis [62]. Subsidies for farmers and land-owners are financed $75 \%$ by the Flemish government, and $25 \%$ by the municipality, whilst construction costs of mitigation measures are financed $75 \%$ by the government, $15 \%$ by the province, and $10 \%$ by the municipality [63]. These incentive-based measures are well accepted and adopted by farmers in the Flanders region. Personal visits from farm advisers (partly paid by the government) to facilitate the delivery of policy measures to farmers are heralded as the formula for success in the adoption of measures by farmers. As a result of this personal approach, farmers are more confident, cooperative and know who to contact for questions, as demonstrated by interview responses from Flemish farmers [24]. Lessons could be learned from this case study for application to other countries where soil erosion is a problem, including Northern Ireland. Voluntary agri-environmental schemes in Northern Ireland are also available through the Northern Ireland Rural Development Programme. The Northern Ireland Countryside Management Scheme [64] is one such scheme, but is aimed predominantly at enhancing biodiversity, and does not provide funding for measures to reduce soil erosion and its impacts. An erosion policy at a national level is an important means to gain institutional memory in managing the problem of soil erosion and muddy floods [65]. Government support of funding in the form of an erosion-specific agri-environmental scheme to help implement conservation measures could be greatly effective in reducing erosion in high-risk areas. According to [66], however, the current range of EU policies, schemes and directives has the potential to address all recognised soil degradation processes throughout the EU, without the need for specific schemes.

\subsection{Research Required to Facilitate Suggested Approaches}

Policy must, however, if it is to have some evidence base, lag behind research [29]. As demonstrated in Britain, it may take some time to persuade policy makers that there is a problem which needs to be addressed. Monitoring of erosion and runoff are critical to enable appropriate policy making, not only to know the severity of present-day erosion but also as a basis to help build and validate models to project future erosion rates to help inform future policy. In the flow diagram representing these phases in Figure 3, the situation with regards to Northern Ireland is currently only at the "recognition" stage. Some modeling work (e.g., [11-15]) has been carried out in Northern Ireland, but long-term measured data does not currently exist. The European Commission Land Resource Management Unit has collected data on soil erosion throughout Europe [67], but the UK is not one of the contributing countries. Data from the Republic of Ireland could be used as an approximate analogue for Northern Ireland, but long-term field-based data at a local field-scale is required to more 
precisely determine the extent of the problem in the present day. It is postulated that only when soil erosion and its impacts are recognised as a problem by farmers as well as policy makers, and considerable long-term monitoring of erosion has been conducted, will consideration be given to the types of changes in policy outlined in this paper.

Figure 3. Stages required to achieve necessary adaptation measures for controlling soil erosion now and in the future and their current status in Northern Ireland (after [24]).

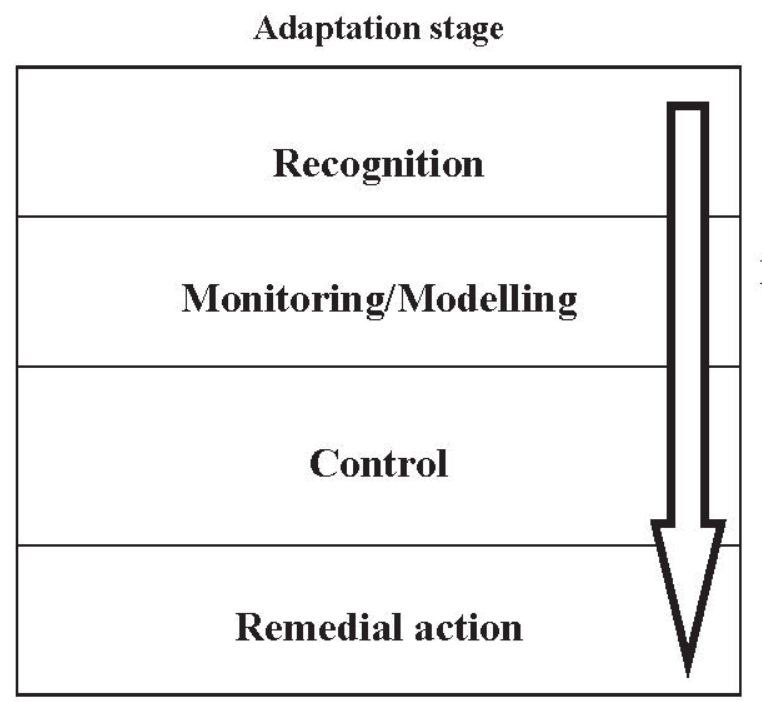

Current status in Northern Ireland

Partially by policy makers, less so by farmers

Event-based measurement only and modelling from [11-15]

Influence of SFP cross-compliance and

implementation of agri-environmental

schemes

Evidence of some erosion control in past and present-day (see [14]).

\section{Conclusions}

The off-site impacts of soil erosion in terms of sedimentation and nutrient enrichment of surface waters are a present-day problem in Northern Ireland, and recent studies have projected how these issues may become more serious under the impacts of future climate change. This review paper has examined the policies in place to manage erosion in Northern Ireland, and has sought to evaluate their effectiveness, before offering some suggestions on how policies may be reshaped to better manage an escalating problem. Soil erosion and its impacts are currently managed in an indirect way by the Common Agricultural Policy and a number of associated agri-environmental schemes, yet farmers are often not keeping their land in good agricultural and environmental condition, leading particularly to off-site impacts of erosion which are affecting water quality. Suggestions for policy changes were then offered, including a range of measures at a range of spatial scales. In terms of changes at the EU level, such as reforms to the WFD and the CAP, the use of clearer environmental standards for water quality targets may provide a more rigorous basis for ensuring thresholds are not exceeded. At a governmental level, ideas include greater enforcement of subsidy requirements, educating farmers on soil erosion prevention and remediation, implementation of conservation measures in high-risk zones as part of the SFP cross-compliance, and consideration to the development of voluntary agri-environmental schemes aimed directly at reducing soil erosion. The need for long-term measured erosion data to help raise awareness amongst farmers and policy makers, as well as help validate models to assess the future problem is a pressing research requirement to help ensure such measures can be taken in the future to manage a problem which looks set to worsen over the coming decades. 


\section{Acknowledgments}

As this research was largely undertaken as part of my Ph.D., I wish to acknowledge my supervisors Dave Favis-Mortlock (University of Oxford) and Rowan Fealy (NUI Maynooth) for their help with the future modelled data which lies behind some of the ideas examined in this paper. I am also grateful to The Department of Employment and Learning Northern Ireland for funding my Ph.D.

\section{Conflicts of interest}

The author declares no conflict of interest.

\section{References}

1. Soil Quality and Soil Erosion; Lal, R., Ed.; Soil and Water Conservation Society: Ankeny, IA, USA, 1999.

2. Morgan, R.P.C. Soil Erosion and Conservation, 3rd ed.; Blackwell Publishing Limited: Oxford, UK, 2005.

3. He, X.; Zhou, J.; Zhang, X.; Tang, K. Soil erosion response to climatic change and human activity during the Quaternary on the Loess Plateau, China. Reg. Environ. Chang. 2006, 6, 62-70.

4. Lal, R.; Stewart, B.A. Soil Degradation; Springer-Verlag: New York, NY, USA, 1990.

5. Pimentel, D. Soil erosion: A food and environmental threat. Environ. Dev. Sustain. 2006, 8, 119-137.

6. Langdale, G.W.; West, L.T.; Bruce, R.R.; Miller, W.P.; Thomas, A.W. Restoration of eroded soil with conservation tillage. Soil Technol. 1992, 5, 81-90.

7. Pimentel, D.; Harvey, C.; Resosudarmo, P.; Sinclair, K.; Kurz, D.; MnCair, M.; Crist, S.; Shpritz, L.; Fitton, L.; Saffouri, R.; et al. Environmental and economic costs of soil erosion and conservation benefits. Science 1995, 267, 1117-1123.

8. Wardle, D.A.; Bardgett, R.D.; Klironomos, J.N.; Setälä, H.; van der Putten, W.H.; Wall, D.H. Ecological linkages between aboveground and belowground biota. Science 2004, 304, 1634-1637.

9. Boardman, J. A short history of muddy floods. Land Degrad. Dev. 2010, 21, 303-309.

10. Boardman, J.; Shepheard, M.L.; Walker, E.; Foster, I.D.L. Soil erosion and risk-assessment for on- and off-farm impacts: A test case using the Midhurst area, West Sussex, UK. J. Environ. Manag. 2009, doi:10.1016/j.jenvman.2009.01.018.

11. Mullan, D.J.; Favis-Mortlock, D.T.; Fealy, R. Addressing key limitations associated with modelling soil erosion under the impacts of future climate change. Agric. For. Meteorol. 2012, 156, 18-30.

12. Mullan, D.J.; Favis-Mortlock, D.T. Managing soil erosion: A case study from Ireland. Geogr. Rev. 2011, 24, 24-26.

13. Favis-Mortlock, D.T.; Mullan, D.J. Soil Erosion by Water under Future Climate Change. In Soil Hydrology, Land Use and Agriculture: Measurement and Modelling; Shukla, M., Ed.; CABI Publishing: Wallingford, UK, 2011; pp. 384-414.

14. Mullan, D.J. Soil erosion on agricultural land in the north of Ireland: Past, present and future potential. Ir. Geogr. 2013, doi:10.1080/00750778.2013.776216.

15. Mullan, D.J. Soil erosion under the impacts of future climate change: Assessing the statistical significance of future changes and the potential on-site and off-site problems. Catena 2013, 109, 234-246. 
16. Favis-Mortlock, D.T.; Savabi, M.R. Shifts in Rates and Spatial Distributions of Soil Erosion and Deposition under Climate Change. In Advances in Hillslope Processes; Anderson, M.G., Brooks, S.M., Eds.; Wiley: Chichester, UK, 1996; Volume 1.

17. Williams, J.; Nearing, M.A.; Nicks, A.; Skidmore, E.; Valentine, C.; King, K.; Savabi, R. Using soil erosion models for global change studies. J. Soil Water Conserv. 1996, 51, 381-385.

18. Favis-Mortlock, D.T.; Guerra, A.J.T. The implications of general circulation model estimates of rainfall for future erosion: A case study from Brazil. Catena 1999, 37, 329-354.

19. Nearing, M.A. Potential changes in rainfall erosivity in the U.S. with climate change during the 21st century. J. Soil Water Conserv. 2001, 56, 229-232.

20. Pruski, F.F.; Nearing, M.A. Climate-induced changes in erosion during the 21 st century for eight U.S. locations. Water Resour. Res. 2002, 38, Article 1298.

21. Trenberth, K.E.; Dai, A.; Rasmussen, R.M.; Parsons, D.B. The changing character of precipitation. Bull. Am. Meteorol. Soc. 2003, 84, 1205-1217.

22. Nearing, M.A.; Jetten, V.; Baffaut, C.; Cerdan, O.; Couturier, A.; Hernandez, M.; Le Bissonnais, Y.; Nichols, M.H.; Nunes, J.P.; Renschler, C.S.; et al. Modeling response of soil erosion and runoff to changes in precipitation and cover. Catena 2005, 61, 131-154.

23. Rosenzweig, C.; Hillel, D. Climate Change and the Global Harvest. Potential Impacts of the Greenhouse Effect on Agriculture; Oxford University Press Inc.: New York, NY, USA, 1998.

24. Verspecht, A.; Vandermeulen, V.; de Bolle, S.; Moeskops, B.; Vermang, J.; van den Bossche, A.; van Huylenbroeck, G.; de Neve, S. Integrated policy approach to mitigate soil erosion in West Flanders. Land Degrad. Dev. 2011, 22, 84-96.

25. Prazan, J.; Dumbrovsky, M. Soil conservation policies: Conditions for their effectiveness in the Czech Republic. Land Degrad. Dev. 2010, 21, 124-133.

26. Schuler, J.; Sattler, C. The estimation of agricultural policy effects on soil erosion-An application for the bio-economic model MODAM, 2010. Land Use Policy 2010, 27, 61-69.

27. Lundekvam, H.E.; Romstad, E.; Øygarden, L. Agricultural policies in Norway and effects on soil erosion. Environ. Sci. Policy 2003, 6, 57-67.

28. Boellstorff, D.; Benito, G. Impacts of set-aside policy on the risk of soil erosion in central Spain. Agric. Ecosyst. Environ. 2005, 107, 231-243.

29. Evans, R. Runoff and soil erosion in arable Britain: Changes in perception and policy since 1945. Environ. Sci. Policy 2010, 13, 141-149.

30. DEFRA. Piloting a Cost-Effective Framework for Monitoring Soil Erosion in England and Wales; SP1311; Department for Environment Food and Rural Affairs: London, UK, 2013.

31. European Commission. Thematic Strategy for Soil Protection (Communication); Brussels, 22-9-2006. COM (2006) 231 final; European Commission: Brussels, Belgium, 2006.

32. Jones, A.; Panagos, P.; Barcelo, S.; Bouraoui, F.; Bosco, C.; Dewitte, O.; Gardi, C.; Erhard, M.; Hervás, J.; Hiederer, R.; et al. The State of Soil in Europe; European Commission Joint Research Centre: Ispra, Italy, 2012.

33. European Commission. Common Agricultural Policy. A Partnership between Europe and Farmers; Publications Office of the European Union: Luxembourg, Luxembourg, 2012; p. 16. 
34. DEFRA. Soil Protection Review 2010 GAEC 1; Department for Environment Food and Rural Affairs: London, UK, 2010.

35. European Commission. Establishing a Framework for Community Action in the Field of Water Policy; Directive 2000/60/EC of the European Parliament and of the Council; European Commission: Brussels, Belgium, 2000.

36. Lilly, A.; Grieve, I.C.; Jordan, C.; Baggaley, N.J.; Birnie, R.V.; Futter, M.N.; Higgins, A.; Hough, R.; Jones, M.; Noland, A.J.; et al. Climate Change, Land Management and Erosion in the Organic and Organo-Mineral Soils in Scotland and Northern Ireland; Scottish Natural Heritage Commissioned Report No. 325 (ROAME No. F06AC104-SNIFFER UKCC21); Scottish Natural Heritage: Edinburgh, Scotland, UK, 2009.

37. DEFRA. Common Agricultural Policy Reform, (On-Line), Department for the Environment, Food and Rural Affairs, London, 2011. Available online: http://www.defra.gov.uk/foodfarm/farm-manage/cap-reform/ (accessed on 12 October 2011).

38. Royal Commission on Environmental Pollution (RCEP). Sustainable Use of Soil; 19th Report; Her Majesty's Stationery Office (HMSO): London, UK, 1996.

39. Silvey, V. The contribution of new varieties to cereal yields in England and Wales between 1947 and 1983. J. Natl. Inst. Agric. Bot. 1986, 17, 155-168.

40. Baird, W.W.; Tarrant, J.R. Hedgerow Destruction in Norfolk 1946-1970; School of Environmental Sciences, University of East Anglia: Norwich, UK, 1973.

41. Environment Agency. The State of the Environment of England and Wales: The Land; Environment Agency, Her Majesty's Stationery Office: London, UK, 2000.

42. Evans, R.; Cook, S. Soil erosion in Britain. SEESOIL 1986, 3, 28-59.

43. Favis-Mortlock, D.T. Ireland. In Soil Erosion in Europe; Boardman, J., Poesen, J., Eds.; Wiley: Chichester, UK, 2006.

44. Robinson, D.A. Agricultural practice, climate change and the soil erosion hazard in parts of southeast England. Appl. Geogr. 1999, 19, 13-27.

45. Boardman, J. Soil erosion and flooding on the eastern South Downs, southern England, 1976-2001. Trans. Inst. Br. Geogr. 2003, 28, 176-196.

46. Boardman, J.; Evans, R.; Ford, J. Muddy floods on the South Downs, southern England: Problem and responses. Environ. Sci. Policy 2003, 6, 69-83.

47. Evans, R.; Boardman, J. Curtailment of muddy floods in the Sompting catchment, West Sussex, southern England. Soil Use Manag. 2003, 19, 223-231.

48. Evans, R. Curtailing water erosion of cultivated land: An example from north Norfolk, eastern England. Earth Surf. Processes Landf. 2006, 31, 598-605.

49. European Commission. On Support for Rural Development from the European Agricultural Guidance and Guarantee Fund; Council Regulation (EC) No. 1257/1999; European Commission: Brussels, Belgium, 1999.

50. Department of Agriculture and Rural Development (DARD). Farm Nutrient Management Scheme (Northern Ireland) 2005 Scheme Booklet FNMS I; Department of Agriculture and Rural Development: Belfast, UK, 2005; p. 50. 
51. Fealy, R.; Sweeney, J. Statistical downscaling of temperature, radiation and potential evapotranspiration to produce a multiple GCM ensemble mean for a selection of sites in Ireland. Ir. Geogr. 2008, 41, 1-27.

52. Mullan, D.J.; Fealy, R.; Favis-Mortlock, D.T. Developing site-specific future temperature scenarios for Northern Ireland: Addressing key issues employing a statistical downscaling approach. Int. J. Climatol. 2012, 32, 2007-2019.

53. Lempert, R.; Nakicenovic, N.; Sarewitz, D.; Schlesinger, M. Characterizing climate change uncertainties for decision-makers - an editorial essay. Clim. Chang. 2004, 65, 1-9.

54. European Commission. On the Quality of Fresh Waters Needing Protection or Improvement in Order to Support Fish Life; Directive 2006/44/EC of the European Parliament and of the Council; European Commission: Brussels, Belgium, 2006.

55. Collins, A.L.; Anthony, S.G. Assessing the likelihood of catchments across England and Wales meeting "good ecological status" due to sediment contributions from agricultural sources. Environ. Sci. Policy 2008, 11, 163-170.

56. Verheijen, F.G.A.; Jones, R.J.A.; Rickson, R.J.; Smith, C.J. Tolerable versus actual soil erosion rates in Europe. Earth Sci. Rev. 2009, 94, 23-38.

57. DARD. Guide to the Single Farm Payment (SFP) Scheme; Department of Agriculture and Rural Development: Belfast, UK, 2011; p. 39.

58. MAFF. Soil Erosion by Water. ADAS Leaflet 890; Ministry of Agriculture, Fisheries and Food: Alnwick, UK, 1985.

59. DEFRA. Controlling Soil Erosion: A Manual for the Assessment and Management of Agricultural Land at Risk of Water Erosion in Lowland England; Revised September 2005; Department for the Environment, Food and Rural Affairs: London, UK, 2005.

60. Rural Payments Agency (RPA). Single Payment Scheme: Cross-Compliance Guidance for Soil Management 2010 Edition; Rural Payments Agency/Department for Environment Food and Rural Affairs: London, UK, 2010; p. 76.

61. Evans, R. Outdoor pigs and flooding: an English case study. Soil Use Manag. 2004, 20, 178-181.

62. Verstraten, G.; Poesen, J.; Govers, G.; Gillijns, K.; van Rompaey, A.; van Oost, K. Integrating science, policy and farmers to reduce soil loss and sediment delivery in Flanders, Belgium. Environ. Sci. Policy 2003, 6, 95-103.

63. Vandaele, K.; Lammens, J.; Priemen, P.; Evrard, E. How to control muddy floods from cultivated catchments? Lessons from the Melsterbeek catchment in Flanders (Belgium), (On-line), Samenkering Land en water, St-Truiden, Belgium, 2013. Available online: http://www.land-enwater.be/english.html (accessed on 3 March 2013).

64. DARD. Countryside Management Scheme (Northern Ireland); Scheme Information Booklet; Department of Agriculture and Rural Development: Belfast, UK, 2007; p. 144.

65. Boardman, J.; Vandaele, K. Soil erosion, muddy floods and the need for institutional memory. Area 2010, 42, 502-513.

66. Louwagie, G.; Gay, H.S.; Sammeth, F.; Ratinger, T. The potential of European Union Policies to address soil degradation in agriculture. Land Degrad. Dev. 2009, 22, 5-17. 
67. Panagos, P.; van Liedekerke, M.; Jones, A.; Montanarella, L. European Soil Data Centre (ESDAC): Response to European policy support and public data requirements. Land Use Policy 2012, 29, 329-338.

(C) 2013 by the authors; licensee MDPI, Basel, Switzerland. This article is an open access article distributed under the terms and conditions of the Creative Commons Attribution license (http://creativecommons.org/licenses/by/3.0/). 